\title{
The United Congregational Church of Southern Africa (UCCSA) - A case study of a united and ecumenical church ${ }^{1}$
}

D van der Water ${ }^{2}$

(University of Pretoria)

\begin{abstract}
The United Congregational Church of Southern Africa (UCCSA) - A case study of a united and ecumenical church
\end{abstract}

In this article, the ecumenical heritage of the United Congregational Church of Southern Africa is described by the General Secretary of that church. The early history of the UCCSA, related to the London Missionary Society, created a sense of self-awareness that led to the unification of racially divided congregational churches during 1967. This set the ground for the active involvement of the UCCSA in the political liberation processes in Southern Africa. In addition, the UCCSA's continued exploration of further ecumenical endeavours is traced. The covenental theology of the UCCSA forms a unifying thread throughout these processes.

\section{THE ECUMENICAL HERITAGE OF THE UCCSA}

"Born out of and for unity" (Wing 1990). This ecumenical principle, which undergirded the birth of Congregationalism in Africa, was to characterise the life, work and witness of the Congregational churches in Southern Africa since 1799 until the present time ${ }^{3}$. Although structural and organic unity amongst the three strands of Congregationalism ${ }^{4}$ only

\footnotetext{
'This article was first published in Lombaard, C (ed.) 1999: Essays and exercises in ecumenism. Pietermaritzburg: Cluster Publications, 234-244. It is republished here with the permission of the editor and the publisher - because of the divergent readership of these two publications.

${ }^{2}$ Research Associate: Department of Church History, University of Pretoria \& General Secretary: United Congregational Church of Southern Africa.

${ }^{3}$ Congregationalism in South Africa was established by the London Missionary Society (LMS), the fundamental principle and stated approach of which was not to create church denominations in the countries of their missionary endeavours, but to proclaim "the Glorious Gospel of the blessed God" (CWM [Council for World Mission] 1990:21).

${ }^{4}$ The first strand of Congregationalism is that which came as an outflow of the $18^{\text {th }}$ century Evangelical Revival in England. In 1799 the LMS sent Dr J T van der Kemp as a missionary to South Africa, and with his coming Congregationalism took root in African soil. A second strand is that which comes from America, whereby
} 
materialised in 1967, ecumenical co-operation was a feature of this family of Reformed churches for many decades prior to union ${ }^{5}$.

The historical event of the union by which the Congregational family of churches became one was described by the late Rev. Joseph Wing, first General Secretary of the newly formed United Congregational Church of Southern Africa (UCCSA), as follows (Wing 1986:61):

"On October 3, 1967 we went into a Durban church as three distinct denominational bodies and came out AS ONE PEOPLE, and despite stresses and strains, disagreement and some defections, we have remained ONE PEOPLE ever since."

At the historic service of worship, the three uniting churches, namely the London Missionary Society, the Bantu Congregational Church, and the Congregational Union of South Africa, in the manner of Congregationalists, entered into a solemn covenant. The following words of the covenant, which is incorporated into the Order of Service for the Lord's Supper, has become part of the liturgical life of the UCCSA (UCCSA/ELD 1980:41):

"We believe in God our heavenly Father.

We confess Jesus Christ as Lord and Saviour.

We depend on the guidance of the Holy Spirit.

We seek to live in God's presence according to all that he has made known to us or will make known to us.

We covenant to worship, work and witness together in the fellowship of the United Congregational Church of Southern Africa for the building up of the Body of Christ and manifestation of the Kingdom of God on earth."

Thus, a united church was born which, firstly, acknowledged a common ancestry in the arrival of the first LMS missionaries at the Cape in 1799, and secondly, was spread over five countries of Southern Africa, namely

missionaries from the American Board Mission (ABM), led by Daniel Lindley and Newton Adams, came to South Africa in 1835. The ABM founded the Bantu Congregational Church in South Africa. Thirdly, when the LMS withdrew from the Cape Colony, the churches it had founded formed themselves into the Evangelical Voluntary Union in 1859, later (in 1877) to become the Congregational Union of South Africa (CUSA) (cf. Wing 1986).

${ }^{5}$ For more than a century, the three churches of Congregational origin in Southern Africa, namely the LMS, ABM and CUSA, continued as separate denominations, but nurtured close fraternal and formal links. In 1961, therefore, a Joint Committee of the three churches was set up to explore the uniting of the total work and witness of these Congregational denominations (cf. Wing 1986).

THE UNITED CONGREGATIONAL CHURCH
Botswana, Mozambique, South West Africa (Namibia), South Africa and Rhodesia (Zimbabwe).

However, the unity experienced by the UCCSA at the time of its inauguration was not static. Within 24 hours of uniting, the church committed itself to seeking union with the Anglican, Methodist and Presbyterian churches. Together with these churches, the UCCSA therefore founded the Church Unity Commission (CUC), a body mandated to faciliate and engage these churches in conversations and actions towards structural unity (Wing 1991).

Before the end of 1967, the UCCSA revived bilateral union negotiations with the Presbyterian Church of Southern Africa (PCSA), which soon resulted in schemes for united congregations and the mutual eligibility of members and ministers of these respective two churches. Another step, in the quest for greater church unity, was achieved in 1972, only five years after the birth of the UCCSA, when the Disciples of Christ (South African Association) merged with the UCCSA. Two unions within the space of five years earned for the UCCSA the appellation of "trend-setters" in ecumenical affairs.

Although committing itself passionately to the search for even greater church unity, the UCCSA at no stage perceived this endeavour as an end in itself. The Rev. J K Main, in his chairperson's address at the occasion of union in 1967 , declared that "the test of our coming together lies in the purpose for which we are united" (Main 1967). That "purpose" was, according to Main (1967), "to be a more effective witness in the world in which God has set us, in the age in which God has called us".

\section{SOCIO-POLITICAL CHALLENGES FACING THE NEWLY UNITED CHURCH}

The UCCSA's resolve, namely to be "a more effective witness in the world", was to be severely tested in the ensuing years and decades to come. In particular, the challenge facing the church and its ecumenical partners in South Africa was to represent the vanguard of Christian witness in the face of increasing violence and oppression under apartheid rule.

The year of the UCCSA's birth as a united church, namely 1967 , for example, saw the passing of the Terrorism Act in South Africa. This Act, which eroded the rule of law and denied individuals the right to be regarded as innocent until proven guilty, was arguably the most totalitarian piece of legislation ever enacted in South Africa. The UCCSA, like other churches and Christians opposed to the policies of apartheid, lived in the shadow of this legislation for almost three decades until its scrapping from the statute books. Ministers and laity within the UCCSA, including

ISSN 1609-9982 = VERBUM ET ECCLESIA Jrg 22 (1) 2001 
women and children, languished in detention, some for months and even years $^{6}$.

UCCSA churches and church members in other Southern African countries such as Botswana, Namibia, Zimbabwe and Mozambique were also directly and indirectly affected by the aggression of the apartheid regime, especially through cross-border raids ${ }^{7}$. The UCCSA roundly condemned such acts of terror perpetrated by the state and the apartheid legislation, such as the Terrorism Act, which was clearly promulgated to perpetuate the status quo and to crush any opposition.

Invariably, an ethos of repeated expressions of opposition to apartheid began to characterise the nature of the church's pronouncements and resolutions, especially at the UCCSA's annual Assemblies. In terms of the church's constitution, the Assembly is the most authoritative and most representative of the denomination's bodies (UCCSA 1986:13, Clause 6.f). In 1968, for example, the UCCSA joined its voice with other ecumenical churches by endorsing the Message to the people of South Africa ${ }^{8}$, an SACC document which denounced the policies and practices of apartheid as fundamentally opposed to the Gospel message.

In response to the UCCSA and other ecumenical churches' opposition to apartheid, the Prime Minister of South Africa, Mr B J Vorster, lambasted the churches and all clergy who took such a stand, warning them against what he regarded as ministers using the pulpit for political ends (quoted by Wing 1990).

The UCCSA, however, was not prepared to limit the Word of God and the Gospel to a narrow-minded or other-wordly piety. The confrontation between the advocates of a conventional piety and the supporters of strong social action to end apartheid came to a head in 1970 when the World Council of Churches (WCC) made its controversial grants to the liberation movements ${ }^{9}$. Within the UCCSA it emerged beyond any

${ }^{6}$ For example, the Rev. Benjamin Ngidi, a minister of the UCCSA, was detained while lecturing at the Federal Theological Seminary of Southern Africa (FEDSEM). The Rev. Ngidi, also a former chair of the church, was held in detention for a continuous period of thirteen months, before being finally released without being charged in 1978 .

${ }^{7}$ The most devastating of such raids was an air-strike by the South African Defence Force (SADF) on Gaborone, Botswana, on June 14, 1985, in which twelve people were killed, six people were wounded and much property destroyed (cf. Nyelele \& Drake 1986).

${ }^{8}$ The Message to the people of South Africa, was published in 1986 by the Theological Commission of the South African Council of Churches (SACC). The SACC had invited churches to sign the document as an expression of their commitment to the struggle against apartheid.

9 The controversy over the WCC Programme to Combat Racism reared its head again and again in debates during UCCSA Assembly sessions from 1970 to 1975. shadow of doubt that the black majority of the UCCSA's members saw the WCC programme as a gesture of support for the oppressed peoples of Southern Africa, while the mainly white minority perceived it as the church supporting terrorism. However, the polarisation which manifested itself in the debates on the WCC grants reflected the growing conflict in attitudes amongst the Congregationalists on issues of socio-political concern.

With the turn of the new decade, that is the 1980s, the UCCSA as a church affirmed its commitment to a ministry and mission in which social responsibility and political involvement was an integral part, often in open defiance of the overt and covert threats from the National Party government. The church, however, in outlining its position vis-à-vis social responsibility, also acknowledged its own failure in not consistently upholding and practising the Christian principles that it advocated (UCCSA 1980):

"Notwithstanding the fact that the UCCSA witnesses in its own life to an allegiance which transcends race and political boundaries and in which loyalty to Jesus Christ is acknowledged as supreme, the UCCSA is caught up in a situation of escalating violence and deteriorating human relations in which issues of Christian principle often become blurred by group or national identity and interests. The Assembly acknowledges in humble repentance that the UCCSA has not always upheld and practised the fundamental principles of the teaching of Christ it has advocated.

Our spiritual unity in the Church has often been a facade hiding the division and hurt in our real life outside the Church."

On the matter of the church's political involvement, the UCCSA insisted that "wherever the Word of God should demand it, the Church should fulfil its prophetic function" (UCCSA 1980), adding though that the "scriptural commandment of neighbourly love is the decisive norm for social justice". These were the principles that the church accepted as the only "common basis for Christian social and political involvement" (UCCSA 1980).

The above position inevitably thrust the UCCSA more and more into the cauldron of socio-political conflict. Notwithstanding, a measure of opposition within the church from some clergy and members, who were unhappy about the UCCSA's relatively high political profile, the

However, the vast majority of UCCSA members consistently supported the church's basic stand on the matter, namely that of remaining a member of the WCC.

ISSN 1609-9982 = VERBUM ET ECCLESIA Jrg 22 (1) 2001 
church found itself embarked on a course of greater confrontation with the policies and practices of apartheid ${ }^{10}$.

This confrontational stance of the UCCSA, vis-à-vis the state was, however, mostly expressed through statements and resolutions taken by its General Assemblies. Whether the church's prophetic voice, which was articulated through such resolutions found an echo and was being effectively translated into action at regional, synodical and local church level, remains a matter of serious concern.

\section{THE ONGOING SEARCH FOR UNION AND FOR ECUME- NICAL WITNESS IN SOCIETY}

The UCCSA's ongoing commitment to church unity and ecumenical activity is clearly expressed by its unbroken membership of, and participation in, such international and national ecumenical organisations as the World Council of Churches (WCC), the World Alliance of Reformed Churches (WARC), the Council for World Mission (CWM), the South African Council of Churches (SACC), the Alliance of Black Reformed Christians of South Africa (ABRECSA), the Church Unity Commission (CUC), and the Wilgespruit Fellowship Centre (WFC).

Notwithstanding a major setback in 1984 when the United Congregational Church of Southern Africa and the Presbyterian Church of Southern Africa failed to bring their protracted initiatives to the point of structural union, these two churches continue to co-operate and collaborate at a number of different levels, for example as united local churches $^{11}$, and with joint theological training for ministry ${ }^{12}$. The

${ }^{10}$ In 1980 , the detention of another prominent UCCSA minister, the Rev. John Thorne, former chair of the church, resulted in an act of defiance by clergy from ecumenical churches. On March 26, 1980, some 53 ministers and lay people marched to John Vorster Square (the South African Police headquarters in Johannesburg) to protest against the arrest and detention of their colleague. The incident drew national and international media attention when 35 of the clerics, amongst whom were Bishop Desmond Tutu of the CPSA, the Rev. Joseph Wing of the UCCSA, and other church leaders, were arrested and detained overnight at John Vorster Square (cf. Ecunews Bulletin 15/1980).

"Both the UCCSA and the PCSA have taken Assembly resolutions binding their respective churches to a rule whereby no new local church should be established unilaterally, and that all new local churches should be created as neither Congregational nor Presbyterian, but as United Churches. A number of such United local churches have been established all over Southern Africa, for example All Saints United Church (Pietermaritzburg), St. Barnabas United Church (Florida), St. Mungo's United Church (Johannesburg), Vryburg United Church (Vryburg), Atlantis United Church (Cape Town), Rondebosch United Church (Cape Town), etcetera.

12 The former Federal Theological Seminary of Southern Africa (Fedsem) represented perhaps the most successful venture in residential ecumenical

THE UNITED CONGREGATIONAL CHURCH prospect, therefore, of an eventual merger remains an achievable and desirable ideal.

In addition to the above bi-lateral arrangement, the UCCSA remains committed to the objective of greater church union, especially with those churches, such as the other Presbyterian', Anglican and Methodist churches of Southern Africa, with whom the UCCSA has been in closer association through the Church Unity Commission. Over and above the quest for church and Christian unity, the UCCSA also continues to affirm its commitment to the realisation of the unity of all humanity under the Fatherhood of God (cf. Eph 4:6).

\section{THE COVENANT BASIS FOR UCCSA'S ECUMENICAL \\ COMMITMENT}

In their ecclesiology Congregationalists are, in essence, covenant people. The founders of Congregationalism firmly believed that the main ingredient that made a group of Christians a church was the covenant. One of the earliest of these covenants was made by the Pilgrims who covenanted to form the Tabernacle Church in Salem, Massachusetts (USA) in 1629 (UCCSA 1987:56):

"We covenant with the Lord and with one another; and do bind ourselves in the presence of God, to walk in all his ways, according as he is pleased to reveal himself unto us in his blessed word of truth."

At the heart of the UCCSA's involvement in ecumenical affairs is a commitment which stems from its covenant obligations, on the one hand to the Lord Jesus Christ, and on the other to the people of God. As such obedience by Congregationalists as Covenant people is the first part of their commitment to the Covenant and its Lord. This obedience takes two directions.

The "new covenant" which Christ offers, includes his New Commandment to love one another as God loves us (cf. Jn 15:12). Christ's love is without limit, and therefore the church may set no boundary to

theological training and ministerial formation. The closure of Fedsem, however, has not signalled the end of ecumenical co-operation at this level, and students for the Christian ministry from these churches still train together at theological colleges and universities such as Rhodes University (Grahamstown), University of the Western Cape (Cape Town), University of Fort Hare (Alice), United Theological College (Harare), Ricatla Seminary (Maputo), the Theological Education by Extension College (Johannesburg), etc.

${ }^{13}$ That is, the Reformed Presbyterian Church of Southern Africa (RPC), the Evangelical Presbyterian Church of Southern Africa (EPC), and the Presbyterian Church in Africa (PCA).

ISSN 1609-9982 = VERBUM ET ECCLESIA Jrg 22 (1) 2001 
the objects of God's love. Congregationalists as such believe that their covenant love should not be limited to those in the same local church, or to those in the same geographical area, or even only to those in the same denomination. Christ's love is all embracing, and therefore his command is general: those who are his covenant people must love "one another" with the same love God bestows on them, so that all may know that they are Jesus' disciples (cf. Jn 13:34f). Their covenant with their Lord commits Congregationalists to love all God's people, far and wide, without distinction. This is the first part of their obedience, and it gears them for ecumenical activity with other Christians. The question of the quest for the ultimate reunion of Christendom, therefore, is implicit in the UCCSA's covenant obedience.

But over and above the ecumenical activity which witnesses to a united and unified Christendom is the ultimate mandate, endorsed by Congregationalists and again founded on their obedience to their covenant Lord, namely the oikoumene, that is the unity of all humankind and of all God's creation. For the UCCSA, therefore, the quest for Christian unity cannot be pursued at the expense of and apart from the church's commitment to and involvement in the struggle for justice in society and for the integrity of God's creation.

\section{Consulted literature}

Briggs, D R 1996: A Covenant Church. Studies in the Polity of the United Congregational Church of Southern Africa in Terms of its Covenant. Johannesburg: UCCSA.

Briggs, D R \& Wing, J 1970: The Harvest and the Hope. The Story of Congregationalism in Southern Africa. Johannesburg: UCCSA.

Council for world mission 1995: Dare to Dream: 200 Years of the London Missionary Society and the Council for World Mission. London: CWM.

Ecunews Bulletin, 15/1980, July 3,1980.

Main, J K 1967: Chairman's address, UCCSA General Assembly, Durban, 1967. (Archives: DP van der water, File No.3.3).

Nyelele, L \& Drake, E 1986. The Raid on Gaborone - June 14, 1985. A memorial. Gaborone.

UCCSA 1987: Pilgrimage of Faith. Confirmation Training Handbook. Johannesburg: UCCSA.

UCCSA 1986. Manual of Constitutions and Procedures of the United Congregagational Church of Southern Africa. Braamfontein: UCCSA.

UCCSA 1980. Report of the Church and Society Department to the UCCSA Assembly. Cape Town: UCCSA.

UCCSA/ELD. 1980. Services for the Baptism of Children and The Lord' Supper. Johannesburg: UCCSA/ELD (Ecumenical Literature Distribution).

Wing, J (ed) 1975. Jesus is Lord. Studies in the Nature of Congregationalism. Johannesburg: UCCSA.
Wing, J 1977. As One People. Commemorating the Tenth Anniversary of the United Congregational Church of Southern Africa, 1967 - 1977. Johannesburg: UCCSA.

Wing, J (ed.) 1986. Pilgrimage of Faith. Confirmation Training Handbook. Johannesburg: UCCSA.

Wing, J (ed.) 1987. Pilgrimage of faith. Confirmation Training Handbook. Johannesburg: UCCSA.

Wing, J 1990. An Overview of the First Two Decades of the United Congregational Church of Southern Africa. Unpublished paper, delivered at the UCCSA's Ministers Convention, Grahamstown, February 1990

Wing, J 1991. The Search for Union, In Touch, March 1991. Johannesburg: Church Unity Commission

Wing J 1994. Southern Africa: Water from the Rock, in Thorougood, B (ed.), Gales of Change - Responding to a Shifting Missionary Context. Geneva: WCC Publications. 